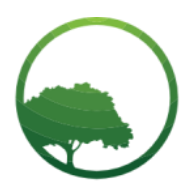

Research in Business \& Social Science

\title{
Influence of credit risk on shareholder market value of commercial banks listed in Nairobi Securities Exchange
}

\author{
Kellen Kiambati@ \\ Karatina University, Nyeri, Kenya
}

Crossref

\begin{tabular}{l} 
A R T I C L E I N F O \\
\hline Article history: \\
Received 28 December 19 \\
Received in revised form 05 Feb 20 \\
Accepted 15 Feb 20 \\
\hline \\
Keywords: \\
Credit, risk, shareholder, market value \\
JEL Classification: \\
G10, E50
\end{tabular}

\begin{abstract}
A B S T R A C T
This study examines the influence of credit risk on the shareholder market value of commercial banks listed in the Nairobi Securities Exchange. A mixed-method approach and concurrent design were used in this study. Logistic regression was performed to ascertain the influence of credit risk on shareholder market value of commercial banks listed in the Nairobi Securities Exchange as a quantitative method and processes tracing as a qualitative approach to trace the causal mechanism by which credit risk contributes to shareholder market value. This research demonstrated that (i)there is a relationship between credit risk and shareholder market value among the commercial banks listed in NSE; (ii) Wald (1) $=41.475, p=.000$, sig<.05, 2-tailed is below the permissible value of likelihood above which null hypothesis is accepted. The study concludes that there is a relationship between credit risks and Shareholders Market Value in commercial banks listed in NSE. () 2020 by the authors. Licensee BSC International Publishing, Istanbul, Turkey. This article is an open access article distributed under the terms and conditions of the Creative Commons Attribution (CC BY) license (http://creativecommons.org/licenses/by/4.0/).
\end{abstract}

\section{Introduction}

Despite the continuous enhancement of financial regulation and supervision in the financial industry, financial risk and credit risks continues to be a great challenge for survival of global financial institutions( Dattels et al., 2010). National Bureau of Economic Research (2015) United Nations of America report indicate that financial crisis and recessions are cyclical and can now be predicted. According to RoK (2013) Central Bank of Kenya guidelines state that the Basel Core Principles for Effective Banking Supervision, 'Risk Management Processes' requires that banks and banking groups must have comprehensive risk management processes (including Board and senior management oversight) to identify, evaluate, monitor and control or mitigate all material risks and to assess their overall capital adequacy in relation to their risk profile. These processes should be commensurate with the size and complexity of the institution. It is therefore a requirement that each institution prepare a comprehensive Risk Management Programme (RMP) tailored to its needs and circumstances. Based on this mandatory requirement, why do we still have variations in credit risk management leading to even collapse of financial institutions? Various studies support that risk affects shareholders market value or lead to collapse of banks. Failure by the banks to properly evaluate credit risk may lead to insolvency and bankruptcy. Aggregated stress testing of Lithuanian banks results in 2002 showed that banks consider credit risk to be the most important risk, constituting over $62 \%$ of possible losses (Ochola, 2010). Also, there is incongruence in the findings of prior studies in regards to the effect of credit risk on Banks financial performance, Gatuhu (2013) investigated the effect of credit risk management on financial performance of MFIs and commercial banks. Studies by Kolapo et al. (2012); Musyoki and Kadubo (2011) found that credit has a negative effect on Banks financial performance. On the other hand, Kithinji (2010) found that credit risk had no effect on Banks financial performance. Afriyie and Akotey (2012) found that credit risk has a positive effect on Banks financial performance. The incongruence in the findings warrants a further study to unearth the optimal effect of credit risk on Banks financial performance. Kithinji (2010) did a study on the effect of credit risk on financial performance of Banks in Kenya and found that profitability of commercial banks is not affected by the magnitude of credit risk exposure. Diverse findings are a clear indication that the causal relationship between credit risk and shareholder value maximization remains complex and warrants further investigation.

* Corresponding author. ORCID ID: 0000-0002-1876-1786

(C) 2020 by the authors. Hosting by SSBFNET. Peer review under responsibility of Center for Strategic Studies in Business and Finance. https://doi.org/10.20525/ijrbs.v9i2.613 
The focus on credit risks and shareholder value maximization is useful because the current collapse of banks in Kenya has largely focused on operational risks and financial risks. Financial risk is a significant factor in the financial market, it determines banks performance, influences the sensitivity of stock returns and the overall health of global economy (Ongore, \& Kusa., 2013). Similar arguments were articulated by Hussein (2014) who states that regulators, shareholders, fund managers being principal stakeholders need to ascertain empirically the relationship of factors of financial risk on shareholder value and market performance.

A well-functioning and profitability banking industry is important for the growth of the economy. In the 2014 CBK report on bank performance, it was noted that a number of listed financial institutions struggled to reach profitability. It was further indicated that banks are now facing a number of challenges that have brought their profitability under pressure but did not specifically and conclusively indicate or cite what the factors are (CBK, 2015, quoted in Omwando, 2017). Credit risks have led to collapse of various commercial banks worldwide credit risk is presumed to date to be the most dominant risk in the banking sector. Similar situation is also in the Republic of Serbia. The typical dominant risk of average commercial bank is credit risk. At the end of third quarter of $2015,86 \%$ of all capital requirements of the bank supervision department were related to the credit risk. The proportion of nonperforming loans to total loans is more than $20 \%$ as opined by (Cecchetti \& Kharroubi, 2012). There was a credit crunch in the United States of America which in turn escalated to a full blown global financial crisis in 2008-2009. Led Leman Brothers a major U.S bank with global presence was declared bankrupt in 2008 thus producing challenges in the global financial market. In the year 2009 to 2015, United States, 486 banks were declared bankrupt. Asset worth 74,777.8 billion dollars were lost (Federal Deposit Insurance Corporation, 2015). African perspective reveals that a significant number of African countries have also had their share of bank failures. The Muslim Bank, Berini Bank and the Lagos Bank were declared bankrupt in 1960. In Zimbabwe, the African Report (2014) reported that, the countries Deposit Protection Corporation has closed down six failed banks namely Sagit finance house, Genesis and Royal, the Century discount house, Rapid discount house and Trust bank with a total cost to depositors of 52.3 million dollars and 11 more banks labeled as financially distressed (Psillaki, Tsolas, \& DMargaritis, 2010). In Ghana's banking sector, the following Banks' collapsed, Bank for Credit, the National Savings, Bank for housing and construction, Commerce International, Meridian BIAO bank, Tano Agya Rural Bank, Ghana Co-operative Bank, Tana Rural Bank, City Savings and Loans, Credit Bank and City Savings and Loans. In Kenya's banking sector, Imperial Bank, Dubai and Chase Bank were declared bankrupt (Mulwa \& Kosgei, 2016). The effective management of credit risk is essential to the long term success of any banking institution. It is therefore essential to scientifically model the influence of credit risk on shareholder market value of commercial banks listed in Nairobi Securities Exchange.

This study acknowledges all the studies and contexts within which they were undertaken. Secondary data will be used to measure the influence of credit risk on shareholder value maximization and data from existing literature collected through process tracing will be used to scientifically model and map out the causal mechanism within which the two variables interact paying attention to possible antecedent factors. The Hypothesis pursued is that there is a relationship between credit risks and Shareholders Market Value in commercial banks listed in NSE.

\section{Literature Review}

The central concept under consideration is credit risk and Fredrick (2012) defines credit risk as the potential that a bank borrower or counterparty will fail to meet its obligation in accordance with agreed terms. With shareholder wealth maximizations as the main aim of organizations, various banking crisis have led to more concentrate measures on credit risk management practices. Specifically, banks serve an essential function in world economy by allocating funds from surplus units to deficits units through their core function of financial intermediation. In undertaking this objective, banks encounter a variety of financial risks which includes; Market risk, credit risk, liquidity risk, operational risk and capital adequacy risk (Tai, 2000; Rahman, 2010). It is the mandate of banks to maintain a Loan Loss Provision account to provide for probability of default by its borrowers. The provisions are established to report incurred impairment losses either on specific loan assets or within a portfolio (Citi Group, 2015). As such, it is expected that an increase in credit risk increases the loan loss provision which is netted off against the interest income and loan assets. This translates to reduced income and profits for a bank. It also increases the liability position of the bank which affects its ratios which investors use to assess its financial performance and position. Worldwide, Saeed and Zahid (2016) analyzed the effects of credit risk on banks' profitability. The study used the UK's top five commercial banks, the researchers considered Return on Equity (ROE) and Return on Assets (ROA) as a profitability measure, which was measured against the credit risk metrics. This was covered for the period between 2007 and 2015, which covered the financial crisis. The United Kingdom experienced a credit crunch in 2007/2008 (Pettinger, 2016). This was a spillover of the crisis experienced USA. This led to banks such as Northern Rock experiencing shortfalls and seeking support from the Bank of England (Bank of England: Annual Report, 2012) which also led to depositors withdrawing their savings. This also led to banks struggling to finance their balance sheets, falling house prices, and expensive mortgages, a key product for banks (Pettinger, 2016). The results of the study showed that despite this crisis, the credit risk indicators depicted a positive correlation with profitability.

According to a study by Isanzu (2017) seeking to establish the effect of credit risk on Chinese commercial banks between 2008 and 2014 , it was established that banks needed to manage their credit risk as a significant relationship existed between the aforementioned risk and the financial performance of the banks. The study was carried out in China on the five largest commercial banks and utilized a regression model to analyse the data. The study recommended improved management of credit risk by the banks (Isanzu, 2017). 
Mendoza \& Rivera (2017), studied rural banks in the Philippines seeking to establish whether a relationship existed between their financial performance and their credit risk levels and their capital adequacy. It was established that a relationship did indeed exist which was negative and statistically significant as analyzed using the Arellano-Bond estimator. However capital adequacy did not have a significant effect on profitability. As such, the authors recommended that rural banks needed to establish whether injection of capital would in any way affect their profitability Vis a Vis increasing their debts (Mendoza \& Rivera, 2017).

Regionally, Kayogire \& Shukla (2016), undertook a case study on Equity Bank (Rwanda) seeking to establish whether their credit risk management policy had an effect on the bank's financial performance. The researchers collected primary data from 57 of the bank's credit officers and established that indeed a relationship existed between the bank's performance and its loan collectability and policies it had put in place to assess lending to its customers (Kagoyire \& Shukla, 2016).

Locally, the Kenyan financial market forms an integrated component of the world economy. Systemic shocks of the global economy have direct or indirect effects on the Kenyan economy. IMF discounted world economic growth 2015 to $3.3 \%$ from the projected $4.2 \%$ due to financial risk and imbalances experienced by the global economy especially the emerging economies. Kenyan economy grew at 5.3\% in 2014 in GDP a slower rate compared 5.7\% in 2013. This growth reduced further to $4.9 \%$ in quarter one of 2015.Although inflation declined to $6.6 \%$ by June 2015 from 7.1\% same period, previous year low oil prices in 2015 did not help the depreciation of the shilling against the US dollar. Kenya Shilling fell to a high of Ksh 105 per US dollar in September 2015 from Ksh 88 per US dollar same period 2014. To stem exchange rate volatility, 91day Treasury bill in a CBK monetary policy review was raised from 8.29\% in Aug 2014 to 14.61\% in September 2015. This increased borrowing cost increasing the level of non-performing loans from 103.7 billion to 124.7 billion in the similar period (CBK, annual report 2015).

During this period of renewed global systemic shocks of 2014/2015, banks profitability increased by $9.3 \%$ although return on asset reduced to $3.3 \%$ from $3.6 \%$. The countries overall public debt increased from $44.2 \%$ to $52.8 \%$ for the year 2014/2015 mainly from external debt of $\$ 2$ billion from Eurobond and Chinese government and Exim bank from China to fund infrastructural development mainly standard gauge railway. This exposure poses a great risk with the country foreign reserve depleting in efforts to stabilization the volatile KSH/USD exchange rate and revaluation of external debt obligations. The reality of adverse effects of financial risk on vulnerable Kenyan economy can be confirmed by the IMF approval to precautionary Stand by Arrangements (SDA) and standby credit facility of US\$ 696.7 million to cushion the economy on possible systemic external shocks (KNBS, 2015).

In Kenyan market, three banks, Imperial Bank, Dubai Bank and Chase Bank have been placed in receivership over the last three years. (Central Bank of Kenya, 2016). According to reports from the Central Bank of Kenya, the receiverships were mainly due to poor corporate governance, failure to maintain adequate capital ratios and liquidity a well as insufficient provisions for NonPerforming Loans (The National Treasury, 2015). In addition, an amendment to the Banking Act in September 2016 introduced the capping of the lending interest rates at 4.0 percent above the CBR with the deposit floor rates at 7 percent of the CBR. In 2017, MOODY's, a global leader in credit ratings, assigned various credit ratings allied to B1, the deposit rating for global foreign-currency of B2 as well as the b1 (BCAs) to Cooperative bank and Equity Bank and in 2016 KCB Bank (Global Credit Research, 2017). The credit rating was against a backdrop of their credit profiles and the two banks' liquidity buffers to withstand their weakened asset quality versus the increased NPLs in an environment characterized by difficult operations (Global Credit Research, 2017).

\section{Credit ratings}

The Credit Rating Agencies (CRA) are mandated to issue credit ratings. This reduces the information asymmetry between lenders and borrowers (Elkhoury, 2008). Their role has been extended due to globalization and the Basel II regulations, which include credit ratings in the weighting rules for credit risk as posited by Basel Committee on Banking Supervision (2008). It is expected that the higher the credit rating, the lower the credit risk and subsequently the better the financial performance of the bank.

\section{Capital adequacy}

Under the current Basel 2 requirements, which have been adopted in Kenya, there exist two kind of capital, which are counted in attaining the required capital adequacy rules. These include supplementary capital and core capital. Based on the traditional approaches to banking, positive characteristics of capital adequacy are needed because capital acts as the buffer against financial performance and losses. Moreover, due to their nature of limited liability, the tendency of commercial banks to engage in activities that have high risks tends to decrease based on the capital at risk compared to the banks' assets. Most importantly, it is worth noting that the performance of banks is incredibly affected by the reduced massive taking of risks (Caprio, Barth \& Levine, 2001).

\section{Loan to deposit ratio}

Ferrouhi (2009) defines liquidity as the extent to which securities or assets or security can be sold or bought in a market without influencing the price of the assets. Note that one of the characteristics of liquidity is an increased level of trading activity. In fact, according to Ferrouhi (2009), assets with the affinity to sell or be bought easily are referred to as liquid assets. Accordingly, Ferrouhi (2009) - in his study on the effects of liquidity of banks on financial performance, the findings clearly exhibit that adequate liquidity prevents the occasions of financial crisis in case of massive withdrawals by the public. Based on Basel 3, Liquidity Coverage Ratio (LCR), on the other hand, aims at ensuring that commercial banks maintain quality liquid assets. Due to the high levels of liquidity, it becomes easier to convert the assets into cash to meet the current needs of the firm. This is also imperative in ensuring that the firm 
meets its requirement for a 30 days calendar under a critically severe scenario of liquidity stress as stipulated by the Net Stable Funding Ratio (NSFR) and supervisors. This is crucial in ensuring that long-term assets can be financed with minimum amount of the firm's stable liabilities compared to the firm's liquidity risk profiles as posited in the Desrochers and Préfontaine (2008).

\section{Conceptual framework}

This study sought to analyze the influence of credit risk on shareholder market value of commercial banks listed in Nairobi Securities Exchange. Credit risk formed the independent variables while Shareholder Market Value was the dependent variables. Credit risk was measured by Credit Rating (CR), Capital Adequacy Ratio (CAR) and Loan to Deposit Ratio (LDR) while shareholder Market Value was measured by ROA and ROE. Figure 1 illustrates the interrelationship between these variables.

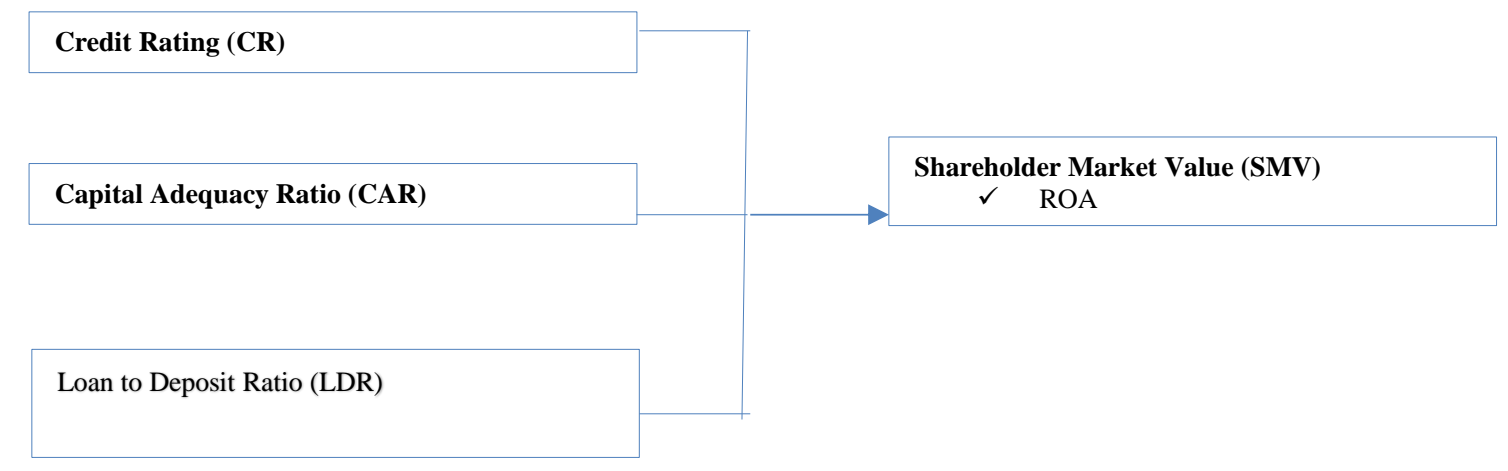

Fig.1: Conceptual framework

\section{Methodology}

This study adopted mixed method approach and Concurrent design was used. A logistic regression was performed to ascertain the influence of credit risk on shareholder market value of commercial banks listed in Nairobi Securities Exchange as quantitative method and processes tracing as qualitative approach to trace the causal mechanism by which credit risk contributes to shareholder Market Value. Time series secondary data obtained from Kenya National Bureau of Statistics, Nairobi Securities Exchange, Central Bank of Kenya, Listed financial institutions historical financial statement and Banking surveys manuals on quarterly basis for the period 2006 to 2015. Therefore, sample will be determined by use of Slovin sampling formula;

$$
n=\frac{N}{1+N\left(e^{2}\right)}
$$

Where, $\mathrm{n}$ is the sample size, $\mathrm{N}$ is the study population and e is the level of precision where in this study its will be taken as 0.05 (95\% confidence level). The population of managers in the listed financial institutions in Nairobi Securities Exchange as at 31 st December 2015 is 2500. (CBK Supervision, 2015).

$$
n=\frac{N}{1+N\left(e^{2}\right)}=\frac{2500}{1+2500\left(0.05^{2}\right)}=
$$

345 Bank Managers

\section{Data analysis}

A logistic regression was performed to ascertain the influence of credit risk on shareholder market value of commercial banks listed in Nairobi Securities Exchange.

$$
\log (\mathrm{p} / 1-\mathrm{p})=\mathrm{b}_{0}+\mathrm{b}_{1} \mathrm{X}_{1}+\mathrm{b}_{2} \mathrm{X}_{2}+\mathrm{b}_{3} \mathrm{X}_{3}+\varepsilon
$$

Where; $\log (\mathrm{p} / 1-\mathrm{p})=$ Shareholder Market Value (SMV)

$\mathrm{X}_{1}=$ Credit Rating

$\mathrm{X}_{2}=$ Capital Adequacy Ratio

$\mathrm{X}_{3}=$ Loan to Deposit Ratio 


$$
\log [\mathrm{p} /(1-\mathrm{p})]=\beta_{0}+\beta_{1} * \text { Credit Rating }+\beta_{2} * \text { Capital Adequacy Ratio }+\beta_{3} * \text { Loan to Deposit Ratio }+\varepsilon
$$

After creating dichotomous dependent variable, the study ran the logistic regression using SPSS set at confidence level of $95 \%$ or Pvalue of 0.05 significance levels.

\section{Results and discussions}

The study processed 340 cases from the secondary data. For every trial we assume there is a probability $97.7 \%$ of positive responses. The distribution of $\mathrm{R}_{2}$ is the Binomial distribution with parameters 337 and $97.7 \%$. Based on this, the study computed corresponding $\mathrm{p}$ for each of each Shareholders Market Value using coefficient $\mathrm{a}$ and $\mathrm{b}$.

Table 1: Parameters of porters variables in the logit regression equation

\begin{tabular}{llllllll}
\hline \multirow{3}{*}{ Step 1a } & & B & S.E. & Wald & Df & Sig. & Exp(B) \\
\cline { 2 - 9 } & $\mathrm{x} 1$ & 2.819 & 1.478 & 3.635 & 1 & .057 & 16.760 \\
\cline { 2 - 9 } & $\mathrm{X} 2$ & 3.098 & 1.637 & 3.582 & 1 & .058 & 22.160 \\
\cline { 2 - 9 } & $\mathrm{X} 3$ & 1.247 & 2.164 & .332 & 1 & .565 & .478 \\
\cline { 2 - 9 }
\end{tabular}

a. Variable(s) entered on step 1: x1, X2, X3.

The results shown in the table 4.16 can be fitted in the equation as;

$$
\log (\mathrm{p} / 1-\mathrm{p})=-1.409+2.819 \mathrm{X}_{1}+3.098 \mathrm{X}_{2}+1.247 \mathrm{X}_{3}
$$

According to the results in the table Credit Rating $(p=.057)$, Capital Adequacy Ratio $(p=.058)$ and Loan to Deposit Ratio ( $p=.565)$ did not significantly add to model/prediction. Using the information in variables in the equation table and logit equation, the study predicted the probability of shareholder value on a unit change in each of credit risks value when all other independent variables (credit risks) are kept constant. The results of the regression equation show that if Shareholders Market Value were rated 0; credit risks value in commercial banks would be -1.409 . However, all three risks had a positive relationship with the shareholders' value. For instance, Credit Rating ( $\left.\mathrm{X}_{1}\right)$ - for every one-unit increase in Credit Rating score (so, for every additional point on the Credit Rating), we expect a 2.819 increase in the log-odds of Shareholders Market Value, holding all other independent variables constant. Capital Adequacy Ratio $\left(\mathrm{X}_{2}\right)$ - For every one-unit increase in Capital Adequacy Ratio score, we expect a 3.098 increase in the logodds of Shareholders Market Value, holding all other independent variables constant. Loan to deposit ratio ( $\mathrm{X}_{3}$ ) - for every one-unit increase in Loan to deposit ratio from existing Loan to deposit ratio, a 1.247 increase in the log-odds of Shareholders Market Value is expected, holding other independent variables constant.

Further the study asses the predictive strength of the logistic regression model. The aim is to find out how well the model can predict the Shareholders Market Value based on credit risks. Using SPSS the study used Cox and Snell Pseudo $-\mathrm{R} 2$ c\&s $=0.87$ and because R2c\&s cannot reach 1, Nagelkerke modified it by increases the Cox and Snell version to make 1 a possible value for R-squared by dividing $\mathrm{R}_{2 c \& s}$ by its upper bond. Based on the model, deviance in the Shareholders Market Values ranges from $8.7 \%$ to $44.7 \%$, depending on whether the Cox $\&$ Snell $R_{2}$ reference or Nagelkerke $R_{2}$ methods, respectively. The model is considered good and fit to predict Shareholders Market Value using Credit Rating, Capital Adequacy Ratio and Loan to deposit ratio because the pseudo R2 are between 0 and 1 .

The findings also demonstrated that $\operatorname{Wald}(1)=41.475, p=.000$, sig $<.05$, 2-tailed is below the permissible value of likelihood above which null hypothesis is accepted. Guided by the rule, the null hypothesis is rejected and alternative accepted. Which means that there is a relationship between credit risks and Shareholders Market Value in commercial banks listed in NSE.

\section{Shareholder market value}

\section{Trend of performance of Kenya's listed commercial banks}

The study sought to establish the trend of performance of the listed commercial banks in Kenya. Secondary from the banks' financial statements and reports for the years between 2008 and 2016 on Return on Assets which was measured as the amount of net income returned as a percentage of total assets. The findings were as illustrated in Figure 2. 


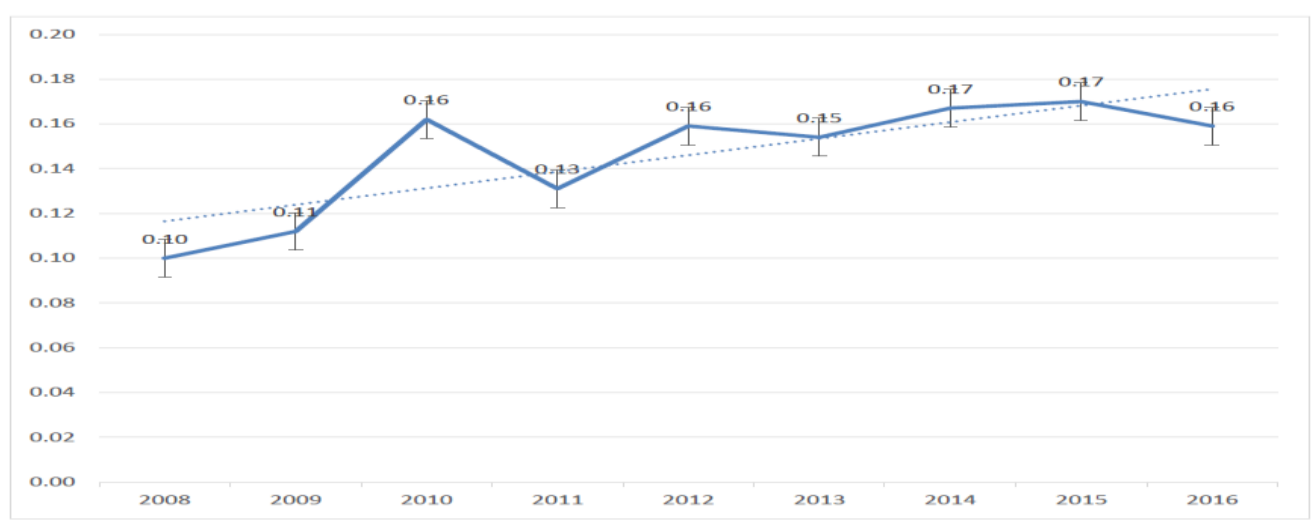

Fig. 2: Trend of performance of Kenya's listed commercial banks; Source: Omwando (2017).

Figure 2 reveals that ROA ranged from 0.10 to 0.17 . From Figure 4.2 it can be observed that there was intermittent performance of banks in terms of ROA between 2008 and 2016, with the highest growth rate being recorded between 2010 and 2011. This may be perhaps explained by the presence of favourable economic growth environment prevailing at that time and therefore means that the shareholders market value at that period was favourable.

\section{Typological theory}

Collier et al (2012) argues that typologies provide the basis for sharpening the theoretical types being investigated in a given study and clarifying the meaning of these types vis-à-vis related concepts. According to Bailey (1994), theory-based typologies can effectively be subjected to rigorous empirical testing using the quantitative models. In this study typological theory has been used as fronted by (George et al., 2005) to allow conceptually sound and analytically productive analysis. The aggregate was divided into three sub-groups with 1 being low, 2 mediums and 3 high. All scores above the mean were considered high and those below the mean were considered low. In the current paper two-dimension figure with four-quadrants was developed.

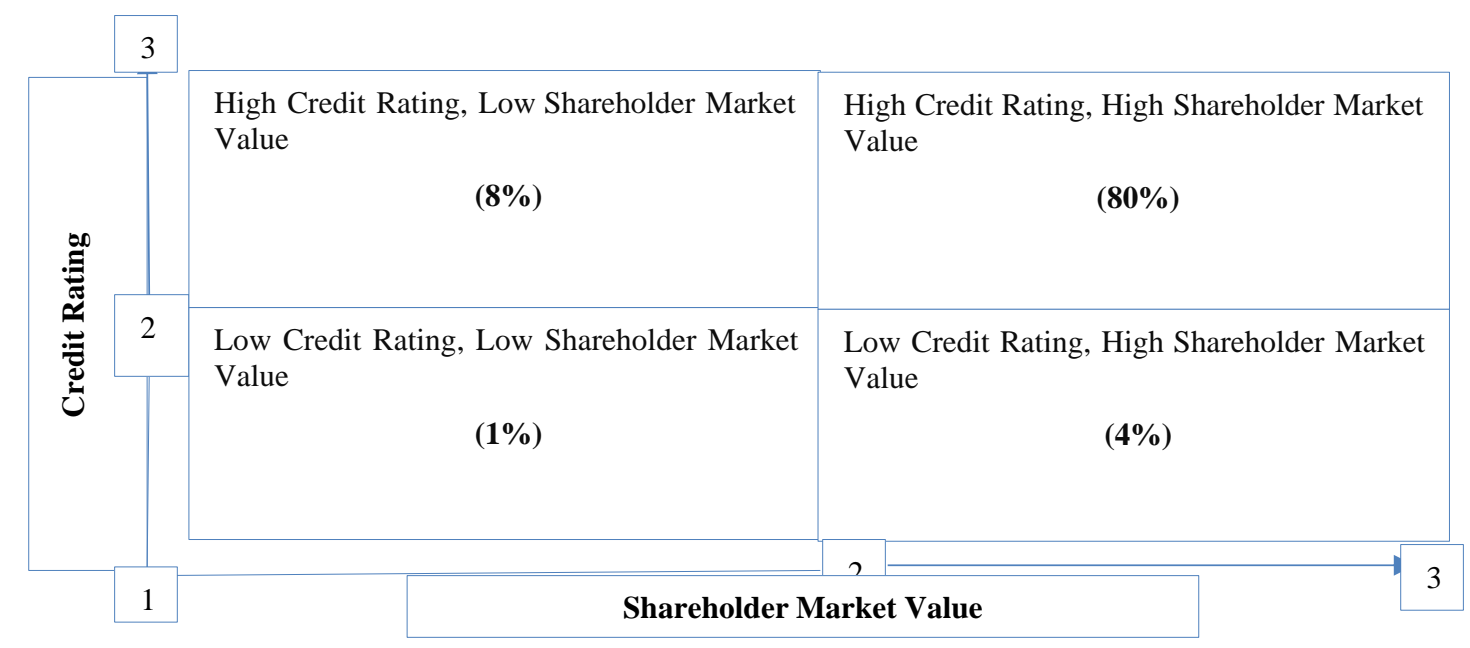

Figure 3: Typology of credit rating and shareholder market value

The commercial banks credit rating is like a bill of health and when the rating is high the company shares are rated high in the trading market and therefore the shareholders market value is considered high and stock can be sold at higher price. 
3

\begin{tabular}{|l|l|l|l|l|}
\hline & $\begin{array}{l}\text { High Capital Adequacy Ratio, Low Shareholder } \\
\text { Market Value }\end{array}$ & $\begin{array}{l}\text { High Capital Adequacy Ratio, High Shareholder } \\
\text { Market Value }\end{array}$ \\
\hline & & $(\mathbf{5 \% )}$ & $\mathbf{( 8 7 \% )}$ \\
\hline
\end{tabular}

Figure 4: Typology of capital adequacy ratio and shareholder market value

When the commercial banks have adequate capital to invest and handle daily activities the company will have a higher shareholder market value. This means that at the stock exchange the company shares can be sold at a higher price unlike when there is no adequate capital ratio.

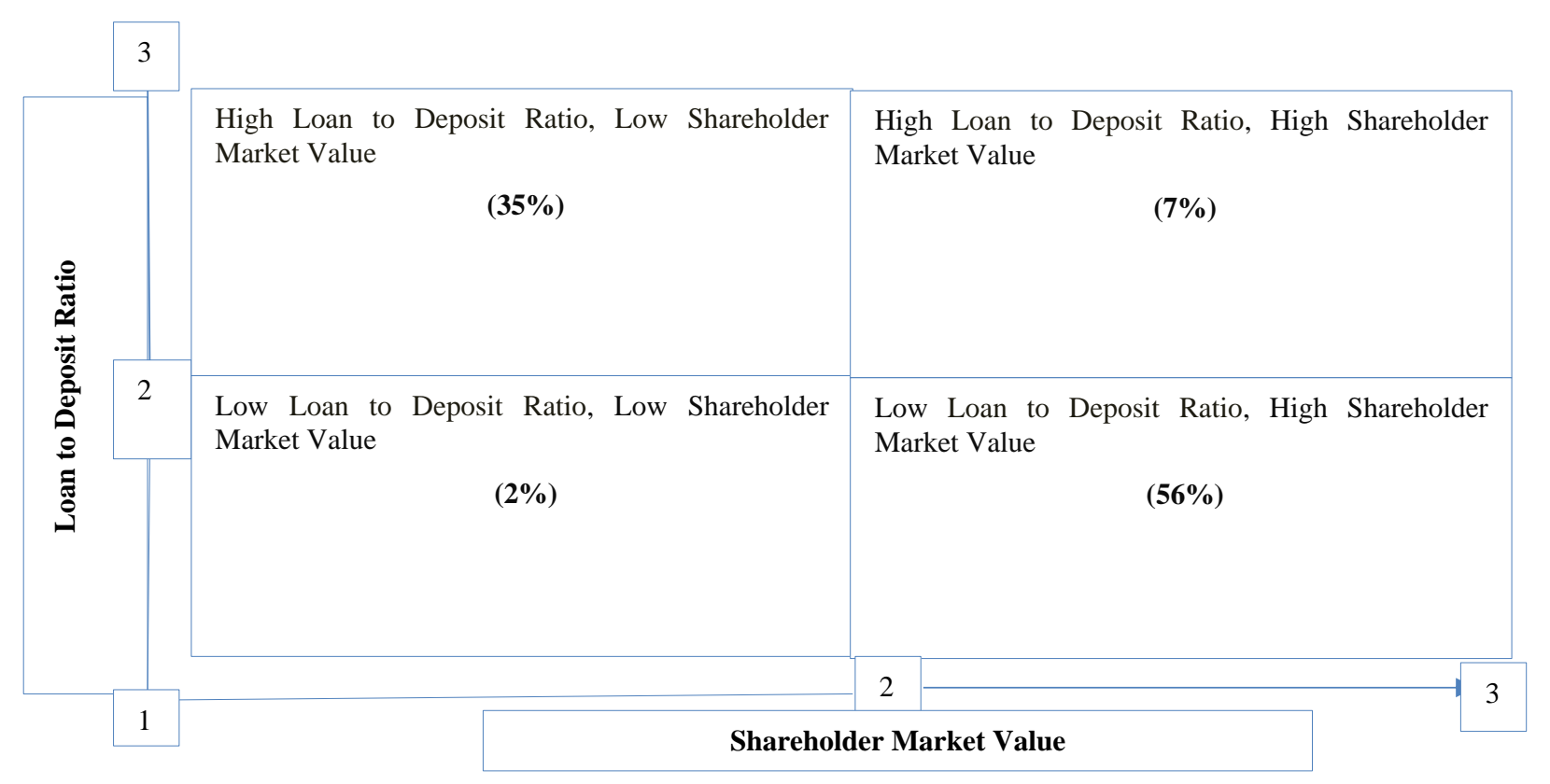

Figure 5: Typology of loan to deposit ratio and shareholder market value

When there is low Loan to Deposit Ratio the Shareholder Market value is said to be doing well and the bank is considered to be performing well as illustrated in figure 4. However, when the ration of high the shareholder market value is low and therefore the shares of the bank will drop in the market. Deposit money banks assume various kinds of risks in the process of providing financial services as lending is the core business activity of banks. The loan portfolio is typically the largest asset and the predominant source of revenue to banks and also one of the greatest sources of risk to a bank's safety and soundness.

\section{Credit risk management and shareholder value maximization: Constructing a pathway}

There is a high level agreement among researchers that generally risk management influences Shareholder Market Value (Sabato, 2010: Fauziah, Zarinah, \& Mohd (2009). The causal mechanism through which this happens is scattered in literature and this section 
aims at demonstrating this mechanism based on process tracing undertaken through various available literature and with the role of credit risk remaining distinct. The antecedent factors contributing to this relationship are also discussed.

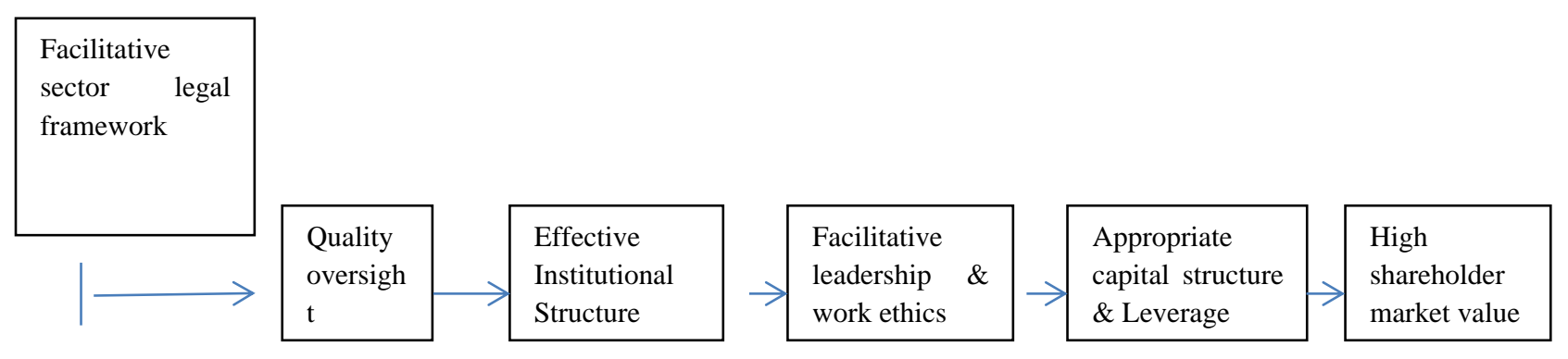

\section{Supportive}

Central Bank \&

bankers

association

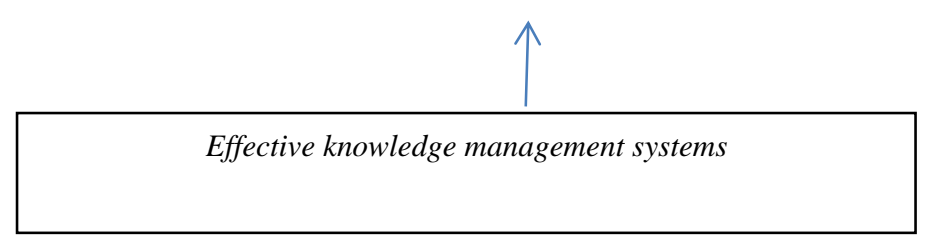

Fig.6: Credit risk and shareholder value maximization pathway

According to RoK (2011), CBK carried out a risk management survey on the Kenyan banking sector in September 2004 with sole objective to determine the needs of the local banking sector with regard to risk management. The survey was necessitated by the drive to fully adopt Risk Based Supervision and to incorporate the international risk management best practices envisioned in the 25 Basel Core Principles for Effective Banking Supervision. The survey culminated in the issuance of the Risk Management Guidelines (RMGs) in 2005 and the adoption of the Risk Based Supervision approach of supervising commercial banks in 2005.

Table 2: The growth recorded after the survey was as follows: -

\begin{tabular}{llc}
\hline Sector Performance & Year performance 2009 & Increase per year 2010 \\
\hline Total assets & KShs 1.35 trillion & KShs 1.69 trillion \\
\hline Deposits & KShs 1.0 trillion & KShs 1.26 trillion \\
\hline Total loans and total liabilities & KShs 915 billion & KShs 1.43 trillion \\
\hline Overall unaudited pre-tax profits & KShs 48.3 billion & KShs 72.4 billion
\end{tabular}

\section{Source: Central Bank of Kenya (2011)}

The active role Kenya Bankers Association (KBA) advocacy and championing of financial sector development through strategic projects created a conjectural relationship of the two antecedent factors of facilitative sector legal framework and supportive Central Bank \& Bankers association in ensuring increased shareholder market value. The supportive and facilitative practices coupled with commitment by players in the sector led to quality oversight necessary for risk management. Structural arrangement which incorporates Chief Risk Officer in the executive management both in the line of reporting and other risk governance mechanism positively influence bank financial performance post financial crisis era (Ellul and Yerramilli, 2012). Effective structures led to appropriate leadership styles and work ethics necessary for productivity, profitability and increased market share as argued by Crook and Ayee (2006). It is more evident in Kenya after the promulgation of new constitution that spelt out leadership and ethics Act to guide public leadership appointments. Masulis (1983), in his study of impact of capital structure change on firm value developed model based on Modigliani and Miller Model (1958) to explain the reaction of stock returns in association with issuer exchange offers supported by appropriate leadership and how it influences wealth transfer. A study by Mathuva (2009) established a positive relationship between Capital adequacy and cost income ratio on performance of commercial banks in Kenya as well as capital to risk weighted asset ratio. Feedback mechanisms through various studies carried out periodically by the Central Bank of Kenya contributed to increase in shareholder market value of commercial banks. This study was inevitably limited in-depth analysis and future studies can be conducted to test the proposed casual pathway in a more detailed manner.

Commercial banks play an intermediary role while at the same time ensuring that body corporates maximize the wealth of their shareholders. Commercial banks generate most revenue by lending credit to customers (Marcucci \& Quagliariello, 2016). Although 
credit facilities are main sources of revenue among commercial banks, loans are however very risky in the banking industry. According to Abdullahi (2013), the issue of credit risk is even of greater concern because of the higher level of perceived risks resulting from some of the characteristics of clients and business conditions that they find themselves in, which needs thorough empirical examinations. Sequel to this, Olalekan and Adeyinka (2013) pointed out that while banks are expected to absorb the losses from the normal earnings, there may be some unanticipated losses which cannot be absorbed by normal earnings.

On loan to deposit ratio, the main profitable activity of the bank is lending money and the underlying principle of lending is risk mitigation, which goes with determining a borrower's ability and propensity to repay the loaned amount. Credit risk management starts with assessing the likelihood of credit risk; determining this risk involves reviewing the borrower's past credit history and earned income. Someone with a good credit rating poses less of a risk than someone with a poor credit history. It is therefore, inevitably not possible to separate banking with credit risk management; which has to be a continuous process and implemented wherever banking business exist. Effective credit-risk management requires financial managers or risk manager to have in depth understanding of the corporate financial risks and how they interrelate with credit risk. Nasieku (2014) carried a study on determinants of NPLs. The study used a case of Commercial bank of Africa. The findings of the study indicated that the existing state of the economy significantly affects NPLs. The study noted that for banks to deal with NPLs, they must put in place proper risk management practices. Similarly, Jerotich et al. (2014) examined how NPLs loans affected performance if commercial banks in Kenya. Relationship between the variables was established through use of correlation analysis. The variables used were GDP, inflation and interest rate spread. The study relied on secondary data collected over a period of 2000 to 2012.

On capital adequacy, the assessment avails important information to banks necessary to identify, measure, monitor and control credit risk as well as to determine that they hold adequate capital against these risks and that they are adequately compensated for risks incurred. increases risk or lower its operating cost. Banks make money from a series of activities of borrowing and deposits but the occurrence of Non preforming Loan (NPLs) and advances is considered as losses to the bank. Higher NPL means higher losses, which adversely influence the banks available capital for further borrowing and hence the efficiency of banks investment is affected, further influencing the profitability. NPLs can be attributed to both macroeconomic conditions and banks specific factors. Excessive risk taking valued by loans-to assets ratio and growth rate of banks loans can as well lead to high NPLs. Ogboi and Unuafe (2013) examined the impact of credit risk and capital adequacy on banks financial performance in Nigeria. Their study used a time series and cross sectional data from 2004-2009 obtained from selected banks annual reports and accounts in Nigeria. Secondary data for the study were obtained from the published financial statement of six out of twenty-one banks operating as at December 2009 which were selected by purposive sampling technique. Panel data model was used to estimate the relationship that exists among loan loss provisions (LLP), loans and advances (LA), non-performing loans (NPL) and capital adequacy (CA) which were the independent variables and return on asset (ROA) as the dependent variable to measure the profitability of the banks. The findings showed that sound credit risk management and capital adequacy impacted positively on bank's financial performance with the exception of loans and advances which was found to have a negative impact on banks' profitability during that period.

\section{Conclusions}

Credit risk remains a critical factor contributing to shareholder market value. Although poor governance has been blamed for inadequate shareholder market value, in this study it is argued that it is important to look into specific factors that can sufficiently explain the dependent variable hence credit risk The credit rating given to commercial banks listed in NSE affects their general performance, this is because many decisions made are pegged on this credit rating. The decisions such as making portfolio allocation decisions and investors rely on credit ratings. Capital has significant influence on ROA, this is because capital acts as the buffer against financial performance and losses and guarantee to depositors that their savings are secure. This means that capital adequacy is key to performance of every commercial banks that is listed in NSE. Finally, loan to deposit ratio is also key to the performance of the commercial banks since the ability of the bank to meet the demand of customers loans and maintain the rate above the requirement by national regulator. Having a high ratio between the two may mean that the bank has many non-performing loans and therefore its shares may be rated as low and therefore affecting the shareholders market value. The findings of this study can help policy formulators in the financial services sector to strengthen the supervisory role and ensure credit risks receive due attention. From the process tracing qualitative data, the study articulates that given the possible explained antecedent factors credit risks, oversight quality, structure, leadership, work ethics and capital structure contribute to shareholder market value. Given the in-depth assessment limitation of this study, future scholars can empirically test the proposed causal mechanism.

\section{References}

Abdullahi, S.R. (2013), Efficacy of credit risk management on the 2006-2010). Global Journal of Management and Business Research Administration and Management, 13(4), 173-199.

Afriyie, H. O., \& Akotey, J. O. (2012). Credit risk management and profitability of selected rural banks in Ghana. Ghana: Catholic University College of Ghana.

Bailey, K.D. (1994) Typologies and Taxonomies: An Introduction to Classification Techniques, 102: Thousand Oaks CA: Sage Publications 
Bank of England (2012). Bank of England Annual Report 2012 Presented to Parliament by the Chief Secretary to the Treasury by Command of Her Majesty available on https://www.bankofengland.co.uk/-/media/boe/files/annual-report/2012/boe-2012

Banking Supervision (2008). Bank Supervision Annual Report Prepared by the Central Bank of Kenya, is available at: http://www.centralbank.go.ke

Caprio, G., Barth, J. R., \& Levine, R. (2001). The Regulation and Supervision of Bank Around the World: A New Database. Brookings-Wharton Papers on Financial Services.

CBK, (2011). Bank Supervision Annual Report Prepared by the Central Bank of Kenya, is available https://www.centralbank.go.ke/uploads/399346751_2015\%20Annual\%20Report.pdf

Cecchetti S. G., \& Kharroubi, E. (2012). Reassessing the impact of finance on growth. Bank for international settlements, BIS working papers, 381 .

Central Bank of Kenya, (2016). Prudential guidelines for institutions licensed under the Banking Act. Central Bank of Kenya. pp. 27-48. [Online] Available: http://wwwcentralbank.go.ke Central Bank of Kenya (CBK)

Citi Group (2015). Citi Group Annul Report. Corporate Governance. New York

Collier, D., LaPorte, J., \& Seawright, J. (2012). Putting typologies to work: Concept formation, measurement, and analytic rigor. Political Research Quarterly, 65(1), 217-232.

Crook, R. and Ayee, J. (2006). Urban Service Partnerships, Street-Level Bureaucrats and Environmental Sanitation in Kumasi and Accra, Ghana: Coping with Organisational Change in the Public Bureaucracy, Development Policy Review 24(1), 51-73

Dattels, P., McCaughrin, R., Miyajima, K and Puig, J. (2010). Can You Map Global Financial Stability? IMF Working Paper No. 2010/145 (Washington: International Monetary Fund).

Desrochers, J. and Préfontaine, J. (2008). Principles for Sound Liquidity Risk Management and Supervision. Basel Committee on Banking Supervision, Working Group on Liquidity, Bank for International Settlements, 9(7), 1-8.

Elasrag, H. (2014). Corporate governance in Islamic Finance: Basic concepts and issues. Available at SSRN. http://dx.doi.org/10.2139/ssrn.2442014

Elkhoury, M. (2008). Credit Rating Agencies and Their Potential Impact on Developing Countries UNCTAD. OSG/DP, (186).

Ellul, A., \& Yerramilli, V. (2013). Stronger risk controls, lower risk: Evidence from US bank holding companies. The Journal of Finance, 68(5), 1757-1803. https://doi.org/10.1111/jofi.12057

Fauziah, H. T, Hamid, Z. and Omar, M. A (2009). The Impact of Financial Risks on Profitability of Malaysian Commercial Banks: 1996-2005. International Journal of Economics and Management Engineering, 3(6) 1320-1334.

Federal Deposit Insurance Corporation, (2015). International Association of Deposit Insurers report. adi.org/en/assets/File/Annual\%20Reports/IADI_Annual_Report_2015-2016.pdf

Ferrouhi, E.M. (2009). Bank Liquidity and Financial Performance: Evidence from Moroccan Banking Industry. Business Theory and Practice, 351-361.

Fredrick, O. (2013). The impact of credit risk management on financial performance of commercial banks in Kenya. DBA Africa Management Review, 3(1).

Gatuhu, R. N. (2013). The Effect of Credit Management on the Financial Performance of Microfinance Institutions in Kenya. Unpublished MBA Project. University of Nairobi

George A.L. and Bennett, A, Lynn-Jones, S. M., \& Miller, S. E. (2005). Case Studies and Theory Development in the Social Sciences. Cambridge, MA: MIT Press. NewYork.

Global Credit Research, (2017). Global Credit Rating Report. GCR South Africa

Isanzu, J. S. (2017). The Impact of Credit Risk on Financial Performance of Chinese Banks. Journal of International Business Research and Marketing, 2(3).

Jerotich, K.N., Asienga, I \& Mutai, R.K. (2014). Determinants of Non-Performing Personal Loans in Kenya's Banking Industry: An Econometric Case Study of Tier One Banks. Journal of Emerging Issues in Economics, Finance and Banking (JEIEFB) An Online International Research Journal 3(6).

Kagoyire, A., \& Shukla, J. (2016). Effect of Credit Management on Performance of Commercial Banks in Rwanda (A Case Study of Equity Bank Rwanda Ltd). International Journal of Business and Management Review, 4(4), 1-12.

Kenya National Bureau of Statistics (2015). 2015/16 Kenya Integrated Household Budget Survey. Government Press, Nairobi Kenya

Kithinji, A. M. (2010). Credit risk management and profitability of commercial banks in Kenya. Unpublished Master's Thesis, University of Nairobi.

Kolapo, T. F., Ayeni, R. K., \& Oke, M. O. (2012). Credit risk and commercial banks' performance in Nigeria: A panel model approach. Australian Journal of Business and Management Research, 2(2), 31-38.

Marcucci J. \& Quagliariello, M. (2016). Is Bank Portfolio Risk Procyclical? Evidence from Italy Using a Vector Auto regression. Journal of International Financial Markets, Institutions and Money, 18(1), 46-63, https://doi.org/10.1016/j.intfin.2006.05.002

Masulis, R. W. (1983). The impact of capital structure change on firm value: Some estimates. The journal of finance, 38(1), 107126.

Mathuva, D. M. (2009). Capital adequacy, cost income ratio and the performance of commercial banks: The Kenyan Scenario. The International journal of applied economics and Finance, 3(2), 35-47. 
Mendoza, R., \& Rivera, J. P. R. (2017). The effect of credit risk and capital adequacy on the profitability of rural banks in the Philippines. Annals of the Alexandru Ioan Cuza University-Economics, 64(1), 83-96. https://doi.org/10.1515/aicue-20170006

Modigliani, F. and Miller, M.H. (1958) The Cost of Capital, Corporation Finance and the Theory of Investment. The American Economic Review, 48, 261-297.

Mulwa, J. M., \& Kosgei, D. (2016). Commercial Bank Diversification and Financial Performance: The Moderating Role of Risk. Journal of Finance and Investment Analysis, 5(2), 31-52.

Musyoki, D., \& Kadubo, A. S. (2011). The impact of credit risk management on the financial network approach. Nigerian Journal of Technology, 28(1), 112-134.

Musyoki, D., \& Kadubo, A. S. (2012). The impact of credit risk management on the financial performance of banks in Kenya for the period. International Journal of Business and Public Management, 2(2), 72-80.

Nasieku, T., Togun, O. R., \& Olubunmi, E. M. (2014). Corporate social responsibility and organizational performance: A theoretical review. International Journal of Humanities Social Sciences and Education, 1(12), 106-114.

National Bureau of Economic Research (2015). Innovation Policy and the Economy. 1-15 (1) University of Chicago Press

Ochola, J. O. (2010). Effect of credit risk management practices on financial performance of commercial banks in Kenya. Unpublished Master's Thesis, University of Nairobi.

Ogboi, C., \& Unuafe, O. K. (2013). Impact of credit risk management and capital adequacy on the financial performance of commercial banks in Nigeria. Journal of emerging issues in economics, finance and banking, 2(3), 703-717.

Olalekan, A., Adeyinka, S. (2013), Capital adequacy and banks' profitability: An empirical evidence from Nigeria. American International Journal of Contemporary Research, 3(10), 102-115.

Omwando, R. ( 2017). Analysis of Factors Influencing the Profitability of Listed Commercial Banks in Kenya. Unpublished Master's Thesis Submitted to the Catholic University of Eastern Africa.

Ongore, V.O. \& Kusa, G.B. (2013). Determinants of Financial Performance of Commercial Banks in Kenya. International Journal of Economics and Financial Issues, 3 (1), 237-252.

Pettinger, M. (2016). Effect of Lower Interest Rates. In Economics Help. Retrieved 11th November, 2019 from -lower-interestrates.

Psillaki, M., Tsolas, I.E., and Margaritis, D. (2010). Evaluation of credit risk based on firm performance, European Journal of Operational Research, 201, (3), 873-881

Rahman, A. A. (2010). Three Factor CAPM risk exposure: Some Evidence from Malaysian Commercial banks. Asian Academy of Management Journal of Accounting and Finance, 6(1), 47-67

RoK (2011). Risk Management Survey for the Banking Sector. Central Bank of Kenya. Available on https://www.centralbank.go.ke/wp-content/uploads/2016/08/Risk-Management-Survey-2010-Report.pdf

RoK (2013). Risk Management Guidelines. Central Bank of Kenya. Available on https://www.centralbank.go.ke/wpcontent/uploads/2016/08/risk-management-guidelines-january-20131.pdf

Sabato, G., 2010. Financial crisis: where did risk management fail? International Review of Applied Financial Issues and Economics 2, 12-18

Saeed, M. S., \& Zahid, N. (2016). The impact of credit risk on profitability of the commercial banks. Journal of Business \& Financial Affairs, 5(2), 2167-0234.

Tai, C.S. (2000). Time-Varying Market, Interest Rates and Exchange Rate Premia in the US Commercial Bank Stock Returns. Journal of Multinational Financial Management, 10(3-4), 397-420.

The African Report (2014). Catalyzing Investment for Transformative Growth in Africa. United Nations New York and Geneva. available on https://unctad.org/en/PublicationsLibrary/aldcafrica2014_en.pdf 